\title{
The Agita São Paulo Program as a model for using physical activity to promote health
}

\author{
Sandra Mahecha Matsudo, ${ }^{1}$ Victor Rodrigues Matsudo, ${ }^{1}$ \\ Timoteo Leandro Araujo, ${ }^{1}$ Douglas Roque Andrade, ${ }^{1}$ \\ Erinaldo Luiz Andrade, ${ }^{1}$ Luis Carlos de Oliveira, ${ }^{1}$ \\ and Glaucia Figueiredo Braggion ${ }^{1}$
}

ABSTRACT The "Agita São Paulo" Program applies a multilevel intervention approach to promoting physical activity among the 37 million inhabitants of the state of São Paulo, Brazil. The verb "agita" means to move the body, but the term also suggests changing the way of thinking and becoming a more active citizen. Since being launched in 1996, the Program has been widely copied throughout Brazil and in other countries of Latin America, and the World Health Organization has characterized it as a model for other developing countries. The Program aims to disseminate a clear and simple message to the community as well as establish partnerships with governmental and nongovernmental organizations and other entities. The Agita São Paulo message encourages people to adopt an active lifestyle by accumulating at least 30 minutes of moderate physical activity per day, on most days of the week. The Program has three main target groups: students, workers, and the elderly. The Program organizes "mega-events" that simultaneously reach and involve large numbers of people, and it also conducts ongoing activities with institutions that become partners of the Program. Intervention studies that the Program has carried out on specific, small groups have found both changes in behavior and an increasing awareness of the Program's name and message. In addition, surveys have found that a growing number of persons in the state of São Paulo have become aware of the Program and its message and have changed their physical activity level. A number of the special features of and lessons learned from the Agita São Paulo Program may have contributed to its success, including: a multisectorial approach; broad use of partnerships; the inclusion principle (avoiding messages or attitudes that might exclude any social group); the scientific basis for all the Program activities; the extensive free media coverage that the Program has received; a "twohats" approach, using either governmental or nongovernmental methodologies to promote physical activity, depending on the circumstances; cultural adaptation (using local culture to disseminate the message and make its assimilation easier); encouraging activities that are pleasurable; the clear, simple, feasible message of promoting physical activity; and evaluation of the various Program efforts. These distinctive characteristics help make the Agita São Paulo Program a model that could be used in other countries as an effective way to promote health through physical activity.

Key words Health promotion, exercise, physical activity, developing countries, Brazil.

1 Agita São Paulo Program-Studies Center of the Physical Fitness Research Laboratory of São Caetano do Sul, São Caetano do Sul, São Paulo, Brazil. Send correspondence to: Sandra Mahecha Mat- sudo, CELAFISCS, Avenida Goiás 1400, São Caetano do Sul-São Paulo, 09521-300-Brazil; fax: 5511-42298980; e-mail: celafiscs@celafiscs.com.br; sandra@celafiscs.com.br
The "Agita São Paulo" Program is a multilevel intervention approach to promoting physical activity among the 
37 million inhabitants of the state of São Paulo, Brazil. While the verb "agita" means to move the body, the term also suggests changing the way of thinking and becoming a more active citizen. The Program was launched in 1996 by the Studies Center of the Physical Fitness Research Laboratory of São Caetano do Sul (Centro de Estudos do Laboratório de Aptidão Física de São Caetano do Sul, or CELAFISCS) and the São Paulo State Secretariat of Health. The Program promotes the recommendation made by Centers for Disease Control and Prevention (CDC) of the United States of America and by the American College of Sports Medicine (ACSM) that everyone should perform at least 30 minutes of moderate-intensity physical activity per day, in one or more sessions each day, on most days of the week. The Agita São Paulo Program has used a number of innovative strategies and activities, which will be described below. Agita São Paulo has been a role model for similar programs in other states of Brazil and in other Latin American countries, and the World Health Organization (WHO) has praised it as a model for other developing countries.

\section{THE STRUCTURE AND SCIENTIFIC FUNDAMENTALS OF THE AGITA SÃO PAULO PROGRAM}

A sedentary lifestyle, which affects as much as $50 \%$ to $80 \%$ of the world's population, is associated with the main risk factors for chronic diseases. For this reason, encouraging an active lifestyle is critical to controlling and preventing these illnesses (1-3). In Brazil, chronic diseases have become an important cause of death, including in the state of São Paulo. Data published in 1990 indicated that the prevalence of a sedentary lifestyle among males and females aged 18 to 70 in the state was $69.3 \%$ (4). In part due to that situation, the Agita São Paulo Program was launched on 5 December 1996 (5). Taking into consideration epidemiological evidence and experiences in other countries, the Program established two primary purposes: (1) to increase people's knowledge of the importance of physical activity as a way to promote health and (2) to increase people's physical activity level. The Program was faced with the difficult task of suggesting that the traditional, structured physical activity programs, such as sports and fitness ones supervised by instructors in health clubs and gyms, are not the only way to promote health among people who are sedentary. Rather than saying "sports is health" or "fitness is heath," the Agita São Paulo Program has taken the position that it takes only minor changes in people's sedentary lifestyles to start gaining the many health benefits that come from an active way of life. The Program has emphasized that this can be done at little or no cost and with less chance of injury than is true for the traditional models of sports and physical fitness, while offering nearly the same health benefits. Shifting from a sedentary lifestyle to one that is slightly active can reduce the risk of death from cardiovascular disease by as much as $44 \%$ (6).

In trying to change the behavior of the general population, the Agita São Paulo Program applies the transtheoretical model of stages of behavior change (7). That model suggests that there are five stages of behavior change: precontemplation (not considering change), contemplation, preparation, action, and maintenance. The Agita São Paulo Program carries out activities that are intended to call people's attention to the importance of a physically active lifestyle and prepares such educational materials as posters, flyers, and brochures that are targeted to population groups in the different behavior change stages. The Program actions and messages are intended to turn sedentary individuals into somewhat active ones, persons who are not very active into active ones, those who are regularly active into even more active ones, and those already very active into individuals able to remain so, at no risk of suffering injury.

\section{The main Agita São Paulo message}

As mentioned above, the main message used by the Agita São Paulo Program to promote the adoption of an active lifestyle was recommended in 1995 by the ACSM and the CDC (8). Those two groups suggested performing at least 30 minutes of moderate physical activity per day, in one session or in several sessions lasting at least 10 minutes each. This new approach has helped people adhere to exercise programs because it addresses the most frequent reason for not doing more exercise: a lack of time (9). Recent scientific studies have assessed energy expenditures and the effect that accumulated physical activity has on physical fitness $(10,11)$. These studies indicate that individuals should expend at least 1500 kilocalories a week on any type of physical activity, which is equivalent to the energy used in walking $15 \mathrm{~km}$ (12). The needed energy expenditures can come from routine, daily activities such as walking, sweeping the floor, running a vacuum cleaner, mowing the lawn, and washing windows (13). These activities can be performed at home, for instance while doing household chores; while carrying out job duties in the workplace and while traveling to and from work; and during pleasurable, leisuretime activities.

\section{The structure of the Agita São Paulo Program}

The Agita São Paulo Program is coordinated by the Studies Center of the Physical Fitness Research Laboratory of São Caetano do Sul, with financial support from the Health Secretariat of the state of São Paulo. The Secretariat oversees the health of 37 million inhabitants in the 645 municipalities in the state.

The Program has two boards that are part of its structure: the Scientific Board and the Executive Board. The Scientific Board consists of both Brazilians and persons from other countries 
who have an academic background and experience in the area of physical activity, including its promotion. These professionals helped establish the Program's scientific foundation and have helped assess the specific activities that have been implemented. A Medical Committee was created as a subunit of the Scientific Board in order to work with the medical community in promoting physical activity.

The Executive Board includes more than 300 governmental, nongovernmental, and private organizations that have joined the Program. These groups represent sectors ranging from health, education, and sports to industry, workers, and the environment. Those organizations are directly responsible for planning, organizing, and carrying out the Program's multiple activities intended to disseminate its message in the community (14). The Executive Board meets once a month to plan and report on activities, to approve new members, and to consider scientific information in the area of physical activity promotion. The Executive Board also publishes a monthly newsletter featuring the activities of all the institutions that are members of the Executive Board.

\section{Expenditures for the Program}

Agita São Paulo has three sources of funding: (1) the State Secretariat of Health; (2) the partner institutions, which contribute resources both directly and indirectly; and (3) businesses, which contribute financial resources for the production of educational and promotional materials.

The direct costs of Agita São Paulo are largely covered by the State Health Secretariat, with a budget of about US\$ 152000 per year. This represents an investment of less than US $\$ 0.01$ per state inhabitant per year. In contrast, the estimated costs of illness related to a sedentary lifestyle in the state are US\$ 37 million per year-about US\$ 1.00 per person per year. Forty percent of the budget amount covers educational and marketing material, 35\% human resources, $14 \%$ research, and $11 \%$ logistics materials and services such as paper, postage, and photocopying and printing.

\section{Strategic actions to promote physical activity in the community}

Although the Program is aimed at all the residents of the state of São Paulo, there are three specific, primary target groups: students, workers, and the elderly (15). To reach these target groups, the Program has undertaken three main types of activities: (1) mega-events, (2) actions carried out with partner institutions, and (3) partnerships.

Mega-events. A mega-event is one that is intended to reach the majority of the cities in the state of São Paulo and/or to involve at least a million people. Mega-events are used to launch new programs and to reinforce older ones, and they are generally linked to such cultural or seasonal events as Labor Day, Carnival, or summer vacation. Because of their size, mega-events often attract broad media coverage, including from television, radio, magazines, newspapers, and the Internet. That attention, in turn, increases awareness of the importance of an active lifestyle.

Some mega-events are held on specific dates for particular audiences, including workers, students, and the elderly. For example, through its "Agita Trabalhador" (Move, Worker) effort, the Program has traditionally taken part in an event conducted by the Brazilian federation of labor unions on 1 May, which is International Labor Day. In the city of São Paulo alone that event involves over one million people in a major demonstration. During the event, special attention is devoted to explaining the Program message to the workers and their family members. The Program has also participated in events that corporations, governmental organizations, and nongovernmental organizations have put on such as the Week to Prevent Work-Related Accidents and other activities that feature physical activity, sports, and recreation.

The most popular mega-event is "Agita Galera" (Move, Crowd; also called the Active Community Day). The Program, with help from the State Education Secretary, dedicates the last Friday in August to disseminating the Program's message throughout the 6800 public schools in the state, to some 6000000 students and 250000 teachers. Each school receives a handbook and a poster specially prepared for this event as well as a special flyer for the students and their families that communicates the Program message of the benefits of physical activity and of accumulating at least 30 minutes of moderate-intensity physical activity per day, on most days of the week. Students are also encouraged to prepare materials of their own through writing, drawing, and photography contests or similar activities that focus on the subject of physical activity. Schools are encouraged to take their students to the community's parks, squares, and clubs so that the students themselves can spread the Program message with street demonstrations and by giving out leaflets and stickers. Ongoing actions are also suggested to the schools such as including the topic of physical activity in classes other than physical education and creating library sections that have books, manuals, and magazines on physical activity and health.

Another mega-event is called "Agita Melhoridade" (Move, Elderly People). The Program organizes a walk on the National Day and the International Day of Older Persons, held in late September. In the past few years this event has also been part of the Global Embrace celebration promoted by the World Health Organization. In this event older adults and senior care centers mobilize each neighborhood and encourage older people and their families to participate in a walking parade. The older people who join in the activities receive T-shirts, fans, and hats on which are printed the Program's message encouraging everyone to accu- 
mulate at least 30 minutes of physical activity every day.

Actions carried out with partner institutions. The Program believes that mega-events alone are not enough to encourage the population to change its behavior in connection with physical activity. Therefore, ongoing activities for promoting the physical activity message have been developed by most of the 300 Program partner institutions to reach the persons served by those institutions as well as the community in general.

The partners can carry out activities that require direct financial investment as well as ones that do not require that investment. Partners can pay for the production of special educational materials such as flyers, posters, videos, and T-shirts that contain "Agita" and the institution's insignia, to use with their own employees or for events that they organize in the community. Other partner activities carry no additional cost, such as printing the message of "accumulate 30 minutes of physical activity every day" on the institution's letterhead, employee pay stubs, or magazine or newsletter. Partners can also put up posters or distribute flyers among their employees and organize lectures or workshops about physical activity and health.

Partnerships. Within the Program the main mission of the 300 partner institutions is to spread the Program message throughout the networks that they have. The Program has avoided inflexible, formalistic mechanisms for adding new partner organizations. A letter of intent may be signed by any group that is willing to contribute to the Program's objectives, without making a rigid commitment. The extent to which each partner commits itself and takes on new responsibilities may grow as it feels more motivated and able to help.

Research conducted in 2000 identified a number of the aspects of the partnerships that have contributed to the Program's success (16). One factor is that the institution that is responsi- ble for coordinating the Program is a research center that was founded in 1974 and has built a strong national and international reputation for its sports sciences research activities. Another aspect is the simplicity of the actions that are proposed: they are easy for partners to organize, and the recommendation of physical activity for health is easy for the general public to understand. A third factor is that the partnerships involve professionals from different areas (e.g., health, sports, social services, and community services) as well as different types of institutions (governmental, nongovernmental, and private) that have a variety of purposes. This diversity of partners has provided a wide range of opportunities to reach target groups and the general population. The diversity has also encouraged innovation and a greater exchange of ideas among the partner institutions. A fourth factor is the technical cooperation that the Program's coordinators provide to the partners, in the form of such materials as pamphlets, manuals, and advertising tools and of scientific information on how to promote physical activity with their employees and the communities that they serve. Each partner institution can decide which strategies and which materials to use.

\section{Working with the municipalities in the state of São Paulo to promote physical activity}

The Agita São Paulo Program has found it highly effective to work with the municipalities in the state to promote physical activity in the general population. Because of the cultural, economic, and social diversity of the 645 municipalities in the state, no single, rigid model for implementing health promotion efforts is appropriate. In addition, a diversity of approaches allows various effective solutions to the same problem.

The Program offers municipalities a range of suggested strategies that can serve as the basis for their activities, and the Program has also made available educational materials and a pro- gram handbook. Often, a letter of intent is signed during an official ceremony in the municipality, with Agita São Paulo representatives in attendance. Each municipality may select its own program name, but most have chosen to name it Agita and the city's name. Creating a logo has been a very inventive process, involving the community through contests, especially in schools. As with the Agita São Paulo Program, many municipalities hold a monthly meeting for their program, to plan, implement, and monitor activities as well as to solidify local support. So far, the Agita São Paulo Program has established more than 50 municipal committees, in small, medium, and large cities throughout the state.

\section{PROMOTING PHYSICAL ACTIVITY IN THE REST OF BRAZIL}

One noteworthy outcome of the Agita São Paulo Program has been the establishment of a national program in Brazil for physical activity promotion. The Ministry of Health launched this program in 2000 under the name of "Agita Brasil," keeping the original "Agita" name and the same meaning of moving the body, changing the way of thinking, and becoming a more active citizen (17). As with Agita São Paulo, the national program is primarily intended to promote health in the population by increasing people's physical activity level, and it also works with various sectors, including health, education, and sports. The national program is directed to the entire population, but especially to people who are at risk of noncommunicable chronic diseases. To help ensure the implementation of the national efforts, the Ministry of Health has established alliances with both state and local managers of the Unified Health System, which is the public system that delivers health care throughout Brazil. The national Agita program also receives technical and scientific support from the Studies Center of the Physical Fitness Research Laboratory of São Caetano do Sul. Other federal depart- 
ments, state departments, cities, universities, businesses, civil society organizations, and service clubs have been working as partners in the national program. Since Agita Brasil was launched, 30 workshops have been held, in all the states of Brazil. These workshops have brought together representatives from over 600 municipalities as well as more than 2300 "multipliers" such as physicians, nutritionists, nurses, dentists, and physical education teachers.

Another way that Agita São Paulo has had an impact on the rest of Brazil-and elsewhere in Latin America-is through the so-called "twohats approach." This term means that either governmental or nongovernmental methodologies for promoting physical activity can be utilized, depending on the circumstances. With this approach, the Agita São Paulo Program had an impact in a number of states around the country even before the national program with the Ministry of Health was officially launched.

\section{PUBLIC AWARENESS FROM FREE MEDIA EXPOSURE}

The Agita São Paulo Program and its primary message have received broad media attention, without having to pay for that coverage (17). For example, around the time that the Agita Galera event mobilizes the state's school population, as many as 21 million people may hear about the event due to the large amount of press coverage. Every year, reports about this event are carried by at least 30 newspapers and seven television news programs in the state as well as four national television programs. The theme of World Health Day in 2002 was "Agita Mundo-Move for Health." That year, the Agita São Paulo Program was covered in 80 stories in the main newspapers around Brazil; 54 radio shows on 12 different stations, totaling over 3 hours of time; and in 22 television program segments, with a total duration of some 53 minutes. The Discovery Channel cable-television channel broadcast a 17-second advertisement in Spanish and Portuguese in all the Latin American countries six times a day for the 7 days preceding the event as well as on the celebration day itself. The broad media coverage for Agita São Paulo has contributed to growing public awareness of the Program and to changes in behavior $(18,19)$. For example, in 2002 a survey in the city of São Paulo found that $52.9 \%$ of the people interviewed were familiar with the name of the Program.

\section{AGITA SÃO PAULO AND SCIENTIFIC KNOWLEDGE}

Agita São Paulo has always maintained a scientific basis for every action and strategy that it applies as well as for the specific physical activity promotion messages that are delivered. The Program has also tried to share its experience with the scientific community in various fields. Between 1996 and 2002, 17 scientific articles on the Program were published, and 76 presentations of scientific papers were made in Brazil and other countries. The articles and the presentations have covered various aspects of the Program, including its organization, media coverage, and efforts with schools and in the workplace. More than 600 lectures and workshops have been delivered in different kinds of scientific events in Brazil as well as more than 65 other such lectures and workshops in other countries. The Agita São Paulo Program has also made presentations at the headquarters of organizations that include the CDC, WHO, Pan American Health Organization (PAHO), United Nations, and World Bank.

\section{THE PROGRAM'S BROAD IMPACT ON PHYSICAL ACTIVITY LEVELS AND ON KNOWLEDGE OF THE AGITA MESSAGE}

In order to determine the impact of the Program, its staff has conducted various surveys since 1999 to assess changes in the level of physical activ- ity and in knowledge of the Program (recall of its name and of its key message). Some of those surveys have found noticeable changes over time. For example, surveys carried out in 1999 and in 2002 with representative samples of persons in the São Paulo Metropolitan Area (the city and the surrounding area) showed increases over that period in the proportion of persons who were physically active and also in the proportion of persons who were walking for at least $30 \mathrm{~min}-$ utes on 5 or more days per week (20).

Awareness of the Program's message also increased over that 1999-2002 period, both in the São Paulo Metropolitan Area and in the state as a whole. In the São Paulo Metropolitan Area, recall of the objective rose from $19.5 \%$ of the persons surveyed in 1999 to $31.3 \%$ in 2002. In the state overall, recall increased from $9.5 \%$ to $24.0 \%$. The surveys also showed that persons who were aware of the Program were more likely to be physically active. For example, in the state overall in 2002, of the persons who were familiar with the Program, $54.2 \%$ of them were physically active, versus $31.9 \%$ among those not familiar with the Program (18).

\section{IMPACT OF INTERVENTIONS WITH SPECIFIC, SMALL GROUPS}

The impact of the Program has also been evaluated by carrying out research among specific, small groups with whom interventions have been conducted. These small intervention groups have included elderly women, students from a private school, patients with hypertension and diabetes, employees of a federal court, and people from hospitals and other health facilities.

One intervention effort was with elderly women who were already involved in exercise sessions two times per week in a senior center in São Caetano do Sul, which is a town located in the suburbs of the city of São Paulo (21). The intervention consisted of an orientation given once a week for 12 weeks for a group of 62 women (mean age of 61.6 years). Each week, after an 
exercise session, a trained professional involved the group in a chat lasting 5 minutes. The women were encouraged to accumulate at least 30 minutes of moderate physical activity on 5 or more days per week, and the professional suggested different ways to include these 30-minute sessions in their daily routines. The women's physical activity level was measured before and after the 12-week intervention. That showed a significant increase $(P<0.05)$ in both the frequency and duration of moderate physical activities and walking among the women. The frequency of moderate physical activities increased from 3.5 to 5 days per week, and the duration from 40 to 120 minutes per day. These results suggest that even people who are already involved in regular exercise sessions can increase their physical activity level.

Another intervention was with a group of students in a private school, also located in São Caetano do Sul. The students were exposed to the Program's message disseminated in the general community and also through special activities done just in the school. In the community, the students received the message from radio and TV programs, newspapers, magazines, and mega-events. Activities just in the school included short talks during physical education classes, an interview with the school physician that was published in the school newsletter, and inclusion of the Program's message on the school's Web site. A self-reported questionnaire was applied before the intervention and a year later, to two different samples of boys and girls who had a similar educational level and age. The time involved in moderate and vigorous physical activity was estimated, and a threshold of 150 minutes per week was used as the criterion for being "regularly active." Over that one-year period there was a significant change $(P<0.05)$ in the proportions of both males and females who met that criterion. The share of male students who reached that target climbed from $20 \%$ to $40 \%$, and among females the proportion rose from $4 \%$ to $42 \%$.
Another intervention was with a group of patients with hypertension and diabetes who had insurance from a private health insurance company that was one of the Program partners. In 1998 the Program trained a group of more than 100 nurses, social service assistants, psychologists, and other health services providers from the company to use various strategies to disseminate to the company's beneficiaries the recommendation of physical activity for health. After the training the insurance company organized 5minute sessions for patients in doctors' waiting rooms in the city of São Paulo, with a flip chart used to explain the benefits of an active lifestyle. The company also made brief telephone calls to beneficiaries to give suggestions on physical activity. In addition, the insurance company held a lecture once a month where a physician stressed the benefits of physical activity. The company conducted telephone interviews with 6411 patients with hypertension and diabetes to assess the impact of the intervention after a 12-month period, in terms of what proportion of the patients were performing moderate physical activity at least three times per week, of at least 30 minutes per session. That analysis found that the proportion rose from $23 \%$ at the baseline to $53 \%$ after one year.

Another intervention was with a group of 35 employees (both men and women, with an average age of 30.6 years) of a federal court in the city of São Paulo. Before the intervention the employees' stage of behavior change related to physical activity was determined as being precontemplation, contemplation, or action. Once a week for a period of 9 weeks a physical education professional trained by the Program gave the employees a 5-minute session of advice explaining the Program's message of becoming active. The initial assessment of the physical activity behavior stages showed that $5 \%$ of the employees were in the precontemplation stage, $43 \%$ in the contemplation stage, and $52 \%$ in the action stage. After the intervention no employees were in the precontemplation stage, $32 \%$ were in the contemplation stage, and $68 \%$ were in the action stage. The assessment also showed that there was an increase in the proportion of employees who knew about the Program's recommendation to perform at least 30 minutes of moderate physical activity on 5 or more days per week.

A number of interventions have been done in hospitals and other health care centers. In some of these facilities a free space, such as a garage, is made available so that patients, employees, and even nearby residents can come together at a specific time to walk or perform some other type of physical activity. One example of this is the São Mateus Hospital, which is located in a part of the city of São Paulo that is among the city's lowest in socioeconomic level and highest in violence. In 1997 the hospital started a program of liangong, a type of light physical activity that originated in China. The program started with 30 people coming to the hospital twice a week for 12-minute sessions. In 2002 the program was operating in 15 health centers in the area, with more than 3000 people taking part in various forms of exercise. Data collected in 3 of the health centers, from 255 employees, patients, and people in the neighborhood, showed that a large majority of those persons reported improvements in their mood and in the quality of their sleep as well as diminished depression and body aches.

\section{AGITA SÃO PAULO'S IMPACT ON LATIN AMERICA AND ELSEWHERE}

The Program's impact has gone beyond the state of São Paulo and even beyond Brazil. From ideas that were spread by the Program, and in a few cases from advice given directly by the Program, similar programs to promote physical activity have been established elsewhere in Latin America, including in Argentina, Colombia, Costa Rica, Ecuador, Guatemala, Mexico, Panama, Paraguay, Peru, Uruguay, and Venezuela. In addition, Portugal set up the Mexa-se Mais (Move Up) program. These various efforts led in October 2000 to the establishment of the Physi- 
cal Activity Network of the Americas (Red de Actividad Física de las Américas), with strong support from the CDC and PAHO.

As was mentioned earlier, the World Health Organization chose physical activity as the theme for World Health Day 2002; nearly 2000 events were held in 148 countries to mark the occasion. In October 2002 a nongovernmental organization, named for the "Agita Mundo-Move for Health" slogan, had its preliminary meeting in São Paulo. In April 2003 the organization was officially launched, with the support of over 180 international and national institutions. Its main purpose is to encourage physical activity around the world as an instrument to promote people's biological, psychological, and social health. To help achieve this objective, a mega-event, Agita MundoMove for Health Day, has been planned for 6 April of every year. In 2003 , over 2100 events on the five continents celebrated the event.

\section{LIMITATIONS AND FUTURE STRATEGIES}

The Agita São Paulo Program faces a variety of challenges in the near future. These include:

- ensuring that the Program is selfsustainable, not relying on support from governmental organizations
- more effectively disseminating the active lifestyle message among physical education teachers

- increasing activities in such areas as capacity-building, marketing, production of new educational materials, and the use of new electronic devices to communicate the Program's messages to corporations and private schools

- implementing ongoing actions nationwide with various ministries in addition to the Ministry of Health

- improving municipal-level activities

Among the specific activities that the Agita São Paulo Program plans for the next 5 years are ones to:

- strengthen the Program at the municipal level

- turn the Agita São Paulo Program into a nongovernmental organization

- reinforce capacity-building, with special attention given to the community health agents and professionals in the Family Health Program (Programa Saúde da Família), which is a program of the Ministry of Health that has been implemented in all the states of Brazil

- prepare manuals specially addressed to health, education, and sports professionals as well as manuals for the creation of walking groups

- create regional committees in the State of São Paulo

\section{REFERENCES}

1. Blair SN, Cheng Y, Holder JS. Is physical activity or physical fitness more important in defining health benefits? Med Sci Sports Exerc 2001;33(6 Suppl):S379-399.

2. Matsudo V, Matsudo S, Andrade D, Araújo T, Andrade E, Oliveira L, et al. Promotion of physical activity in a developing country: the Agita São Paulo experience. Public Health Nutr 2002;5(1A): 253-261.

3. Vuori IM. Health benefits of physical activity with special reference to interaction with diet. Public Health Nutr 2001;4(2B):517-528.

4. Rego A, Berardo F, Rodrigues S. Fatores de risco para doenças crônico não-transmissíveis: inquérito domiciliar no município de São Paulo, SP (Brasil). Metodologia e resultados preliminares. Rev Saude Publica 1990;24:277-285.

5. Governo do Estado de São Paulo. Manual do Programa Agita São Paulo. São Paulo: Imprensa Oficial do Estado São Paulo; 1998.

6. Secretaria de Estado da Saúde; Programa Agita São Paulo. Isto é Agita São Paulo. São Paulo, Brasil: Midiograf; 2002.

7. Prochaska JO, Marcus BH. The transtheoretical model: applications to exercise. In: Dishman RK, ed. Advances in exercise adherence. Champaign, Illinois, United States of America: Human Kinetics; 1994. Pp. 161-180.

\section{CONCLUSIONS}

After 6 years of implementation a noticeable increase in physical activity and in knowledge of the Program and its message has been seen in the general population and also in smaller, specific groups in the state of São Paulo. The Agita model seems to be effective in promoting physical activity in large populations, even in a developing country.

A number of special characteristics of and lessons learned from the Agita São Paulo Program may have contributed to these results. These attributes include: a multisectorial approach; the broad use of partnerships; the inclusion principle, which means that physical activity can be practiced by anyone; the scientific basis for all the Program activities; the extensive free media coverage; the "two-hats" approach, using either governmental or nongovernmental methodologies to promote physical activity; cultural adaptation, taking into account regional beliefs and values; encouraging physical activity that is pleasurable; the clear, simple, feasible message of promoting health by doing at least 30 minutes of physical activity per day; and evaluating the impact of the various Program efforts. These distinctive characteristics also make the Agita São Paulo Program a model that could be used in other countries as an effective way to promote health through physical activity.
8. Pate RR, Pratt M, Blair SN, Haskell WL, Macera CA, Bouchard $\mathrm{C}$, et al. Physical activity and public health: a recommendation from the Centers for Disease Control and Prevention and the American College of Sports Medicine. JAMA 1995;273(5):402-407.

9. Murphy M, Nevill A, Neville C, Biddle S, Hardman A. Accumulating brisk walking for fitness, cardiovascular risk, and psychological health. Med Sci Sports Exerc 2002;34(9):14681474 .

10. Jakicic JM, Wing RR, Butler BA, Robertson RJ. Prescribing exercise in multiple short bouts versus one continuous bout: effects on adher- 
ence, cardiorespiratory fitness, and weight loss in overweight women. Int J Obes Relat Metab Disord 1995;19(12):893-901.

11. DeBusk RF, Stenestrand U, Sheehan M, Haskell WL. Training effects of long versus short bouts of exercise in healthy subjects. Am J Cardiol 1990;65(15):1010-1013.

12. Dunn AL, Marcus BH, Kampert JB, Garcia ME, Kohl HW, Blair SN. Comparison of lifestyle and structured interventions to increase physical activity and cardiorespiratory fitness: a randomized trial. JAMA 1999;281(4): 327-334.

13. Gunn SM, Brooks AG, Withers RT, Gore CJ, Owen N, Booth ML, et al. Determining energy expenditure during some household and garden tasks. Med Sci Sports Exer 2002;34(2): 895-902.

14. Organización Panamericana de la Salud. A multisectoral coalition in health: Agita São Paulo, una coalición multisectorial en salud. São Paulo, Brasil: Midiograf; 2002.
15. Increasing physical activity. A report on recommendations of the Task Force on Community Preventive Services. MMWR Recomm Rep 2001;50(RR-18):1-14.

16. Figueira Jr. AJ. Potencial da mídia e tecnologia aplicadas no mecanismo de mudança de comportamento através de programas de intervenção de atividade física. Rev Bras Cienc Mov 2000;8(3):39-46.

17. Brasil, Ministério da Saúde, Secretaria de Políticas Públicas, Projeto Promoção da Saúde. Programa nacional de atividade física "Agita Brasil": atividade física e sua contribuição para a qualidade de vida. Rev Saude Publica 2002;36(2):254-256.

18. Matsudo SMM, Matsudo VR, Araújo T, Andrade D, Andrade E, Oliveira L, et al. Nível de atividade física da população do estado de São Paulo: análise de acordo com o gênero, idade, nível sócio-econômico, distribuição geográfica e de conhecimento. Rev Bras Cienc Mov 2002;10(4):41-50.
19. Matsudo VK, Matsudo S, Andrade D, Araujo T, Andrade E, Oliveira LC, et al. 'The Agita São Paulo' model in promoting physical activity. In: Medeiros-Neto G, Halpern A Bouchard C, eds. Progress in obesity research: Montrouge, France: Éditions John Libbey Eurotext; 2003

20. Instituto Municipal Ensino Superior. Pesquisa sócio-econômica do ABC. São Caetano do Sul Brasil: IMES; 2002.

21. Ferreira MT, Matsudo SM, Matsudo VKR, Braggion GF. Efeitos de um programa de orientação de atividade física e nutricional sobre a ingestão alimentar e composição corporal de mulheres fisicamente ativas de 50 a 72 anos de idade. Rev Bras Cienc Mov 2003;11(1):35-40.

Manuscript received 12 December 2002. Revised version accepted for publication on 5 June 2003.
RESUMEN

\section{El Programa Agita São Paulo como modelo para el uso de la actividad física en la promoción de la salud}

El Programa "Agita São Paulo" se basa en la aplicación de intervenciones en distintos niveles para impulsar la actividad física entre los 37 millones de habitantes del estado de São Paulo, Brasil. El verbo "agita" significa sacudir el cuerpo, pero también implica cambiar de actitud y convertirse en un ciudadano más activo. Desde su creación en 1996, el Programa ha sido ampliamente adoptado en muchas partes del Brasil y en otros países de América Latina, y la Organización Mundial de la Salud lo ha usado como modelo para otros países en desarrollo. El Programa tiene por objetivo transmitirle a la comunidad un mensaje claro y sencillo, así como establecer alianzas con organizaciones gubernamentales y no gubernamentales y otras entidades. El mensaje que difunde Agita São Paulo incita a las personas a adoptar un estilo de vida más activo mediante la acumulación de un mínimo de 30 minutos de actividad física moderada al día durante casi todos los días de la semana. El Programa, que está destinado principalmente a estudiantes, trabajadores y personas de edad avanzada, organiza "megaeventos" que abarcan a millones de personas a la vez y continuamente celebra actividades con instituciones que se alían con él. En estudios de intervenciones que el Programa ha llevado a cabo en grupos específicos reducidos se han observado cambios de comportamiento y una mejor captación del nombre del Programa y del mensaje que promulga. Algunas encuestas también han revelado que se está incrementando el número de personas en el estado de São Paulo que se percatan de la existencia del Programa y de su propósito y que como resultado han cambiado su nivel de actividad física. Varias de las características especiales del Programa Agita São Paulo y algunas de las lecciones que nos ha dejado podrían haber contribuido a su éxito, entre ellas su enfoque multisectorial; el establecimiento de numerosas alianzas; la idea de inclusión (evitar todo mensaje o actitud que pueda excluir a un grupo social determinado); las bases científicas que respaldan todas las actividades del Programa; la extensa cobertura gratuita que el Programa ha recibido en los medios de comunicación; el enfoque dual, con aprovechamiento de metodologías de procedencia gubernamental y no gubernamental para promulgar la actividad física, según las circunstancias; la adaptación cultural (uso de la cultura local para diseminar el mensaje y facilitar su asimilación); la promoción de actividades agradables; el mensaje claro, llano y factible de promover la actividad física; y la evaluación de las diversas actividades del Programa. Gracias en parte a estas características distintivas, Agita São Paulo es un modelo que podría aplicarse en otros países para hacer de la actividad física un vehículo para la promoción de la salud. 